\title{
Podalonia affinis (W. Kirby, 1798) (Hymenoptera: Apoidea: Sphecidae), a new host species of the strepsipteran Paraxenos sphecidarum (Dufour, 1837) in Belarus
}

\author{
Podalonia affinis (W. Kirby, 1798) (Hymenoptera: Apoidea: \\ Sphecidae) - новый хозяин веерокрылого \\ Paraxenos spbecidarum (Dufour, 1837) в условиях Беларуси
}

\author{
A.M. Ostrovsky \\ A.M. Островский
}

Gomel State Medical University, Lange Str. 5, Gomel 246000 Belarus. E-mail: Arti301989@mail.ru. Гомельский государственный медицинский университет, ул. Ланге 5, Гомель 246000 Беларусь.

Key words: Podalonia affinis, Paraxenos sphecidarum, new host, Belarus.

Ключевые слова: Podalonia affinis, Paraxenos sphecidarum, новый хозяин, Беларусь.

Abstract. The solitary wasp Podalonia affinis (W. Kirby, 1798) (Hymenoptera: Apoidea: Sphecidae), collected between the dacha settlement «Glushets» and the Mikhal'ki village in September 2019, is newly recorded from Homyel Voblasts of Belarus as a host-species for the strepsipteran Paraxenos sphecidarum (Dufour, 1837).

Резюме. Podalonia affinis (W. Kirby, 1798) - одиночная оса из семейства Sphecidae (Hymenoptera: Apoidea), найденная в Гомельской области между СТ «Глушец» и деревней Михальки (сентябрь 2019), впервые отмечена как хозяин веерокрылого Paraxenos sphecidarum (Dufour, 1837) для Беларуси.

\section{Introduction}

Members of the order Strepsiptera display highly peculiar morphology and lifestyles. They are small to medium sized insects (1.0-7.5 mm long) exhibiting extreme sexual dimorphism [Kinzelbach, 1971; Kathirithamby, 1989]. Free living and flying males have twisted hind wings, while their fore wings are reduced to clublike appendages. Usually endoparasitic and wingless females are known to colonize members of seven insect orders [Kathirithamby, 1989, 2009]. Approximately 600 Strepsiptera species are known to exist globally [Kathirithamby, 2002; Kinzelbach, Pohl, 2003], while 30 species from 7 families are known in Europe [Pohl, 2010; Soon et al., 2011]. There are 4 species registered in Belarus [Medvedev, 1965; Ostrovsky, 2018, 2019a, b].

Paraxenos sphecidarum (Dufour, 1837) (Strepsiptera: Xenidae) is a typical parasite of solitary wasps of the genus Ammophila W. Kirby, 1798 (Hymenoptera: Apoidea: Sphecidae) [Medvedev, 1965; Klaus, 2016]. Until recently, from this genus of sphecid wasps for Belarus only $A$. sabulosa (Linnaeus, 1758) has been recorded as its host [Ostrovsky, 2019a].

\section{Results}

The female of Podalonia affinis (W. Kirby, 1798), a solitary wasp from the family Sphecidae, stylopized by a female of $P$. sphecidarum was captured in Gomel region in the course of faunal studies of Hymenoptera of the South-Eastern Belarus for the first time registered as a new host of this strepsipteron in Republic (Fig. 1).

$$
\begin{gathered}
\text { Podalonia affinis (W. Kirby, 1798) } \\
\text { Fig. } 1 .
\end{gathered}
$$

Material. Republic of Belarus, Gomel Area, sandy road along the mixed forest between the horticultural partnership «Glushets» and Mikhal'ki village, 8.09.2019 - 1 우 of P. affinis stylopized by female of P. sphecidarum. A.M. Ostrovsky leg. et det.

\section{Conclusion}

The genus Podalonia Fernald, 1927 and species Podalonia affinis (W. Kirby, 1798) are new to Belorussia's host of strepsipteron Paraxenos sphecidarum (Dufour, 1837). Before that, in Belarus only A. sabulosa has been recorded as its host of $P$. sphecidarum.

\section{References}

Kathirithamby J. 1989. Review of the Order Strepsiptera // Systematic Entomology. Vol.14. P.41-92.

Kathirithamby J. 2002. Strepsiptera. Twisted-wing parasites. Version 24 September 2002 (under construction). - The Tree of LifeWeb Project. Available at http://tolweb.org/ Strepsiptera/8222/2002.09.24 (accessed 12 February, 2020).

Kathirithamby J. 2009. Host-Parasitoid Associations in Strepsiptera // Annual Review of Entomology. Vol.54. P.227249.

Kinzelbach R.K. 1971. Morphologische Befunde an Fächerflüglern und ihre phylogenetische Bedeutung (Insecta: Strepsiptera) // Zoologica. H.119. S.1-256. 

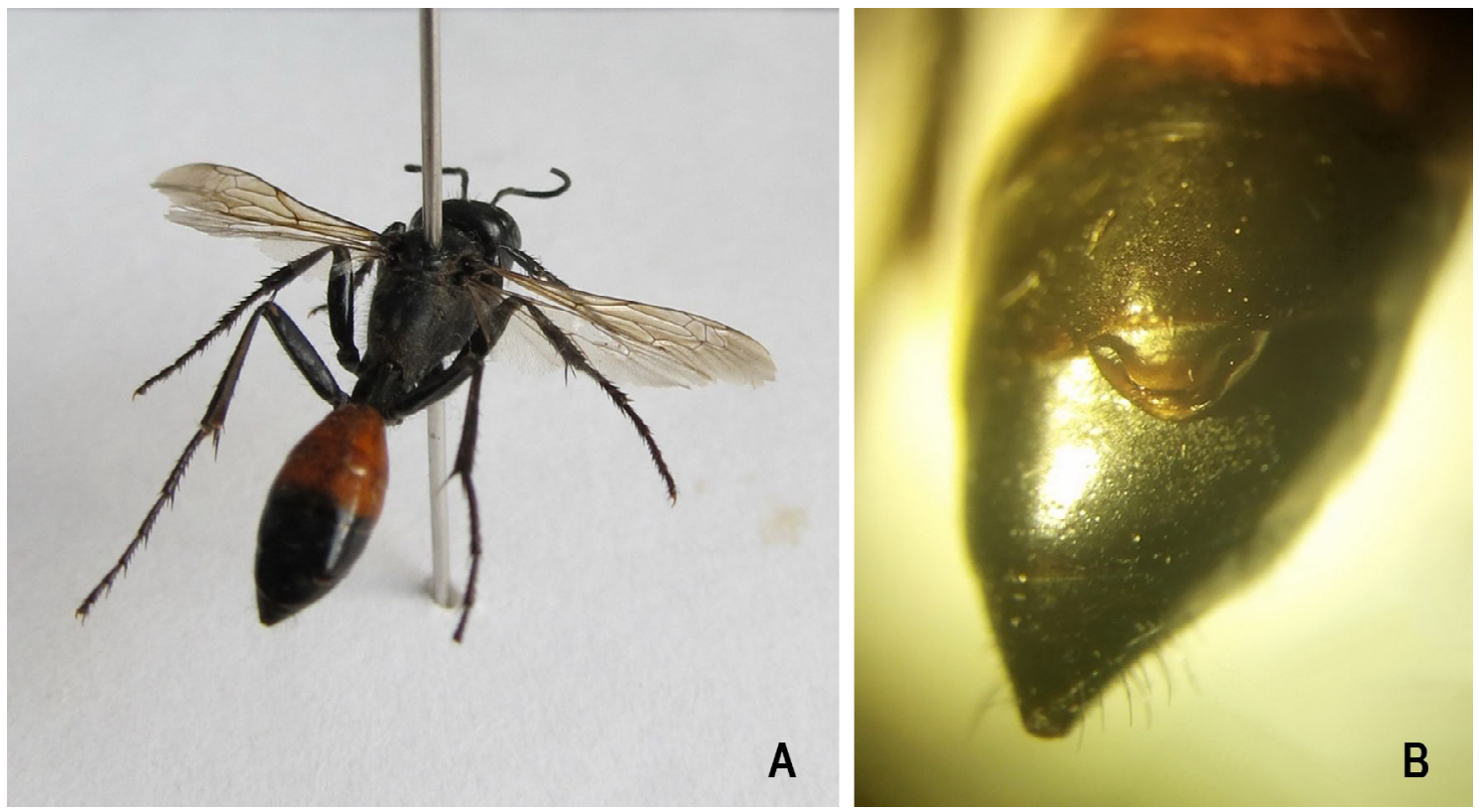

Fig. 1. A - Podalonia affinis: specimen (female) stylopized by a female of Paraxenos sphecidarum; B - Posterior dorsum of female P. affinis showing the cephalothorax female of P. sphecidarum exserted at posterior border of gastral tergums IV and V.

Pис. 1. A - Podalonia affinis: экземпляр (самка), стилопизированный самкой Рaraxenos sphecidarum; В - конец брюшка самки P. affinis с головогрудью самки P. sphecidarum на задней границе IV и V тергитов брюшка.

Kinzelbach R.K., Pohl H. 2003. Ordnung Strepsiptera, Fächerflüger // Wirbellose Tiere. 5. Teil: Insecta. Heidelberg-Berlin: Spektrum Akademischer Verlag. S.526-539.

Klaus M. 2016. Über Fächerflügler (Strepsiptera) bei Hautflüglern (Hymenoptera) in Franken und darüber hinaus // Galathea. Bd.2. S.83-99.

Medvedev L.N. 1965. [The order Strepsiptera] // Keys to the insects of the European part of the USSR. Coleoptera and Strepsiptera. M.-L.: Nauka Publ. Vol.2. P.641-645 [In Russian].

Ostrovsky A.M. 2018. A first record of Stylops melittae Kirby, 1802 (Insecta: Strepsiptera: Stylopidae) in Belarus // Euroasian entomological journal. Vol.17. No.3. P.189-190. DOI: 10.15298/euroasentj.17.3.08
Ostrovsky A.M. 2019a. A new record of strepsipteron Paraxenos sphecidarum (Dufour, 1837), (Insecta, Strepsiptera: Xenidae) from Belarus // Euroasian entomological journal. Vol.18. No.3. P.186-187. DOI: 10.15298/euroasentj.18.3.07.

Ostrovsky A.M. 2019b. Hylecthrus rubi Saunders, 1850 - a new species of strepsipteron (Insecta: Strepsiptera: Stylopidae) in the fauna of Belarus // Euroasian entomological journal. Vol.18. No.6. P.412-413. DOI: 10.15298/ euroasentj.18.6.9.

Pohl H. 2010. Fauna Europaea: Strepsiptera. Fauna Europaea, ver. 2.4. Available at http://www.faunaeur.org (accessed 12 February, 2020).

Soon V., Kesküla T., Kurina O. 2011. Strepsiptera species in Estonia // Entomologica Fennica. Vol.22. P.213-218. 